\title{
Decolorizing Palm Oil Mill Effluent (POME) Using Plant Polysaccharide Degrading Microorganisms Isolated from Soil
}

\author{
Balavinayagamani Ganapathy*, Inthurekha Chanderan, Paulraj Ponnaiah \\ Department of Biomedical Sciences, MAHSA University, Bandar Saujana Putra, Selangor, Malaysia
}

Received: 27 September 2016

Accepted: 13 February 2017

\begin{abstract}
The high color intensity of palm oil mill effluent (POME) is because of the presence of plant constituents and melanoidins produced during Maillard reactions. In this study, various plant polysaccharide degrading microorganisms were isolated from enriched soil and utilized for decolorizing POME. The soil was screened for starch, cellulose, xylan, and chitin degrading microorganisms by using specific media and agar plate screening techniques. Based on the results of scoring, seven isolates were selected and treated with POME collected in liquid form from the palm oil industry in Malaysia. Morphological examinations and Gram staining were done for characterization of the selected isolates. The best three isolates, which were shown their potential for decolorization in terms of percentage of POME, were identified (DE 9, 11, and 17). It was expressed as mean $\pm \mathrm{SD}$. In a seven-day study period of POME with isolates, shaking in room temperature conditions provided maximum percentage of decolorization over that of static in $37^{\circ} \mathrm{C}$ conditions. The maximum percentages of decolorization for DE 9, DE 11, and DE 17 were $35.1 \pm 1.26,20 \pm 1.0$, and $30 \pm 1.0$ on days 6,5 , and 5, respectively. This study primarily focused on decolorizing POME using various plant polysaccharide degrading aerobic bacteria isolated from the soil as an economic method of bioremediation.
\end{abstract}

Keywords: POME, plant polysaccharides, decolorization, bioremediation, BOD, COD

\section{Introduction and Background}

Palm oil is one of the most important economic sources in Malaysia. It is an essential multipurpose vegetable oil used especially for the production of biodiesel, bioethanol, fertilizers, etc. As the second largest palm oil producer in the world, Malaysia exports a million tons of palm oil every year and it is assumed that the rate of palm oil

\footnotetext{
*e-mail: balavinayagamani@gmail.com
}

production increases annually. According to statistical data presented by Ali Huddin Ibrahim et al. (2012), Malaysia generated around 53 million tons of POME in 2008 [1]. Consequently, the production of a large quantity of crude palm oil by the palm oil industry generates a huge amount of dark brownish viscous liquid as a waste from the wet palm oil milling process, which is known as palm oil mill effluent, or POME. The crude palm oil extracted from the fresh fruit produces a very harmful and highly polluting POME that can create environmental pollution [2]. 
Literature studies suggested that the presence of some plant constituents such as lignin, tannin, cellulose, humic acids, and phenolic compounds are responsible for the brown color of the organic POME [3]. The melanoidins formed in the Maillard reaction of carbohydrates with proteins and the release of fatty acids and lipids during the steam extraction process also contribute to the brown color of the acidic effluent [4]. POME is a thick brownish liquid discharged as waste by the palm oil industries. It causes environmental pollution due to its high chemical oxygen demand (COD), biological oxygen demand (BOD), and acidity. A perusal of POME studies found that the chemical components of POME that are present in huge amounts have the potential to cause a severe environmental problem if discharged without treatment into water resources, and also showed that the concentration of COD and BOD of POME were very high. In addition, polysaccharide content was found to be 28.1-30.3 g/L, suggesting the presence of a high amount of dissolved polysaccharides. The concentration of phenol was also found to be higher in POME, which had been reported as 200-1,000 $\mathrm{mg} / \mathrm{L}$. Other components that have been listed were fats, proteins, fibres, total sugars, suspended solids, ash, total nitrogen, and some elements such as phosphorus, potassium, magnesium, calcium, manganese, iron, zinc, copper, chromium, cobalt, cadmium, etc. This high level of chemical composition and brownish viscosity prevents the penetration of sunlight and affects the photosynthesis process of aquatic plants. The chemicals present may chelate with metal ions and become toxic and carcinogenic to the aquatic biota. Hence the impact caused by the discharge of untreated POME is taken into account and the POME is treated properly before being released into the water and other related resources. This is the major concern, and many researchers around the world have come out with different types of studies and methodologies for treating this POME. The discovery of various chemical and physical methods that have been utilized for the removal of the dark brownish color of the POME includes coagulation-flocculation, oxidation, adsorption, electrochemical methods, membrane technology, and activated sludge-granular-activated carbon [5].

Various plant polysaccharides degrading bacteria were screened specifically, since the presence of high polysaccharide content in POME enables the bacteria to utilize these. This idea supports or makes POME decolorization out to be convenient and enable the bacteria to get a constant source of carbon. Hence, different carbohydrate-degrading micro-organisms such as starch, cellulose, xylan, and chitin were screened and isolated from the enriched soil through the agar plate screening technique via various selective media such as starch agar, CMC (Carboxymethyl-cellulose) agar, XC (xylan) media, and CCA (colloidal chitin agar) media.

Measurements of certain parameters are useful for the identification of an effective decolorization by the selected strains, which include COD, BOD, and color intensity.
The use of aerobic bacteria minimizes production costs, is easy to handle, is effective methodology, and complies with environmental regulations without creating any pollution, although it is time-consuming. Furthermore, the strain improvement can be done by recombinant DNA technology to improve the capability of the strain to decolorize the POME more efficiently and reduce the time taken for the process of decolorization. Numerous studies have reported the use of fungi and anaerobic micro-organisms in the study of POME decolorization, and we have found few-to-no reports regarding the use of aerobic bacteria in the effective treatment of POME.

\section{Materials and Methods}

\section{Sample Collection}

The enriched soil samples were collected from an agricultural area of three places around the country in sterilized plastic bags. All the bags were labelled to show the date and site of sample collection and were stored in a dark place under axenic conditions at room temperature. The samples were further processed in laboratory conditions for isolation and identification of microorganisms. The rationale behind the sample collection from the different places was to get the better isolates in rich and can be used for the decolorization of POME efficiently.

\section{Materials}

$\mathrm{XC}$ media, starch, nutrient agar powder, and $\mathrm{CM}$ cellulose were purchased from SRL Laboratories Sdn. Bhd. (Kuala Lumpur, Malaysia). All other chemicals, including alcohol and other nutrient materials for the preparation of the media, were obtained from the Laboratory Department of MAHSA University. All the materials were checked on a regular basis for any sign of contamination before the experiment.

\section{Experimental Design}

Phase 1: Isolation of plant polysaccharide-degrading micro-organisms (starch, cellulose, xylan, and chitin) from the soil.

Phase 2: Checking for decolorization of POME using selected strains isolated from the soil.

$1 \mathrm{~g}$ of soil sample was weighed and mixed with $100 \mathrm{ml}$ of sterile distilled water. The suspension was placed under shaking conditions for $20 \mathrm{~min}$ and serially diluted with sterile distilled water. These serially diluted samples $\left(10^{-1}\right.$ to $\left.10^{-8}\right)$ were plated in nutrient agar for screening of bacterial strains. After 24 hours of incubation, the colonies grown were picked based on their different morphological characteristics and labelled with numbers. We used two letter code followed by the number serially to name them (DE stands for decolorization). 
They were streaked three to four times in nutrient broth to get pure colonies. These isolated strains were cultured in nutrient slants and preserved in glycerol for maintaining the stock culture at $-20^{\circ} \mathrm{C}$. The colonies were identified by Gram staining and colony morphological characters as described by Holt et al. (1994) [6].

\section{Isolating Starch-Degrading Bacteria}

For the isolation of starch-degrading bacteria, the starch agar plates were prepared composed of distilled water $(200 \mathrm{ml})$, beef extract $(0.6 \mathrm{~g})$, soluble starch $(2 \mathrm{~g})$, and agar $(4 \mathrm{~g})$ at $\mathrm{pH}$ 7.5. The cultures stored in nutrient slants were sub-cultured on starch agar and incubated for 24, 48, and 72 hours [7].

\section{Isolating Cellulose-Degrading Bacteria}

The cellulose-degrading bacteria were isolated using CMC (Carboxymethyl-cellulose) agar composed of distilled water $(100 \mathrm{ml})$, peptone $(1 \mathrm{~g}), \mathrm{CMC}(1 \mathrm{~g}), \mathrm{K}_{2} \mathrm{HPO}_{4}$ $(2 \mathrm{~g}), \mathrm{MgSO}_{4} .7 \mathrm{H}_{2} \mathrm{O}(0.3 \mathrm{~g}),\left(\mathrm{NH}_{4}\right)_{2} \mathrm{SO}_{4}(0.25 \mathrm{~g})$, gelatine $(0.2 \mathrm{~g})$, and agar $(2 \mathrm{~g})$ at $\mathrm{pH}$ 7. The isolated cultures were inoculated into the agar plates and incubated for 48 hours. The cellulase-producing bacteria were screened according to the method described by Muhammad Irfan et al. (2012) [8].

\section{Isolating Xylan-Degrading Bacteria}

$\mathrm{XC}$ agar plates were prepared for the isolation of xylan-degrading bacteria. The XC media was composed of distilled water $(200 \mathrm{ml})$, oat spelt xylan $(3 \mathrm{~g})$, peptone $(1.5 \mathrm{~g})$, yeast extract $(0.3 \mathrm{~g}), \mathrm{K}_{2} \mathrm{HPO}_{4}(1.2 \mathrm{~g}), \mathrm{MgSO}_{4} \cdot 7 \mathrm{H}_{2} \mathrm{O}$ $(0.3 \mathrm{~g}), \mathrm{KCl}(0.06 \mathrm{~g}), \mathrm{FeSO}_{4} .7 \mathrm{H}_{2} \mathrm{O}(0.006 \mathrm{~g})$, and agar $(6 \mathrm{~g})$ at $\mathrm{pH}$ 7.0. The isolated cultures were inoculated into the plates and incubated for 24, 48, and 72 hours. For the screening of xylanase-producing bacteria we used the Congo red method [9].

\section{Isolating Chitin-Degrading Bacteria}

The isolation of chitin-degrading bacteria was done by using colloidal chitin agar media (CCA). The colloidal chitin was prepared separately to be included into the media. The colloidal chitin was prepared according to the method described by Priya et al. (2011), where the shrimp shells in the form of flakes were made into powder form as a source of chitin [10].

The CCA media was composed of distilled water $(250 \mathrm{ml}), \mathrm{Na}_{2} \mathrm{HPO}_{4}(0.163 \mathrm{~g}), \mathrm{KH}_{2} \mathrm{PO}_{4}(0.375 \mathrm{~g}), \mathrm{NaCl}$ $(0.0625 \mathrm{~g}), \mathrm{NH}_{4} \mathrm{Cl}(0.125 \mathrm{~g}), \mathrm{MgSO}_{4}(0.03 \mathrm{~g}), \mathrm{CaCl}_{2}$ $(0.0013 \mathrm{~g})$, colloidal chitin $(2.5 \mathrm{~g})$, agar $(4.5 \mathrm{~g})$, and its $\mathrm{pH}$ was adjusted to 6.0. The isolated cultures were inoculated into the CCA plates by single line streaking and incubated for seven days for the formation of a clear zone surrounding the colony [11].

The positive isolates were characterized further by colony morphological characteristics such as colony size, shape, margin, color, elevation, form, and Gram staining as described in Bergey's Manual.

\section{Checking for Decolorization of POME Using Selected Strains}

The selected seven isolates were subcultured in nutrient broth overnight and $5 \mathrm{ml}$ of each bacterial culture were added to the $25 \mathrm{ml}$ of POME in the conical flasks (the volumes of bacterial cultures were standardized before this). The initial absorbance value of untreated POME was measured at $475 \mathrm{~nm}$ wavelength before the addition of bacterial cultures. These treated POME mixtures were incubated for seven days under two different conditions via static, and shaken at twp different temperatures $\left(37^{\circ} \mathrm{C}\right.$ and room temperature). The absorbance values of static and shaken condition-treated POMEs were taken at $475 \mathrm{~nm}$ wavelength for a period of seven days on a daily basis. The untreated and treated POME were diluted to $1 / 10$ dilution using sterile distilled water when taking the initial absorbance readings and the final absorbance readings in order to calculate the percentage of decolorization [12]:

Percentage of POME decolorization, $(\%)=$ $=\frac{\text { Initial absorbance }- \text { Final absorbance X 100\% }}{\text { Initial Absorbance }}$

The readings were taken in triplicate and expressed as a percentage of decolorization in mean $\pm \mathrm{SD}$.

\section{Results and Discussion}

\section{Isolating Polysaccharide-Degrading Microorganisms}

The soil samples collected from three locations were plated and total viable count of bacteria was calculated. This was shown in Table 1. A total of 36 strains named DE-1 to DE-36 were isolated for our study.

Gram's iodine was used to identify the starch degraders, and the formation of a clear zone surrounding the colony indicated the production of amylase enzyme and hydrolysis of starch by the particular strain. Congo red was used to get the clear zone around the colony, which helps to identify the cellulase- and xylanase-producing bacteria, and thus indicated the degradation of cellulose and xylan by the isolate. The isolates with positive results were recorded. The appearance of a clear zone around the colonies was recorded after three days and was considered a positive result for chitinase-producing bacteria.

The total numbers of isolates selected was 36 , which showed positive results and were used to get the scoring shown in Table 2. The scoring method was used to pick up the isolates for further investigation. The criterion behind the scoring method was the screening for extra-cellular enzyme production by various carbohydrates degrading the capacities of organisms 
Table 1. Total viable count (TVC) of isolates from soil collected from different areas in Malaysia.

\begin{tabular}{|c|c|c|c|}
\hline Locations & $\begin{array}{l}\text { Sample } \\
\text { number }\end{array}$ & $\begin{array}{c}\text { Total viable } \\
\text { count } \\
(\mathrm{TVC}) \\
(\mathrm{CFU} / \mathrm{g})\end{array}$ & $\begin{array}{c}\text { Numbers and names } \\
\text { of isolates }\end{array}$ \\
\hline \multirow{3}{*}{$\begin{array}{l}\text { Kulim, } \\
\text { Kedah State }\end{array}$} & 1 & $2.26 \times 10^{6}$ & $\begin{array}{c}\text { DE 1, DE 2, DE 3, } \\
\text { DE } 4\end{array}$ \\
\hline & 2 & $1.38 \times 10^{7}$ & DE 5, DE 6, DE 7 \\
\hline & 3 & $1.58 \times 10^{8}$ & DE 8, DE 9, DE10 \\
\hline \multirow[b]{2}{*}{$\begin{array}{l}\text { Bahau, } \\
\text { Negeri } \\
\text { Sembilan } \\
\text { State }\end{array}$} & 4 & $3.35 \times 10^{8}$ & DE 11, DE 12 \\
\hline & 5 & $1.05 \times 10^{8}$ & $\begin{array}{l}\text { DE } 13, \text { DE } 14, \text { DE } 15, \\
\text { DE } 16, \text { DE } 17, \\
\text { DE } 18, \text { DE } 19, \text { DE } 20, \\
\text { DE } 21\end{array}$ \\
\hline \multirow{4}{*}{$\begin{array}{l}\text { Kota } \\
\text { Damansara, } \\
\text { Kuala } \\
\text { Lumpur }\end{array}$} & 6 & $1.66 \times 10^{6}$ & DE 22, \\
\hline & 7 & $5.09 \times 10^{8}$ & $\begin{array}{l}\text { DE } 23, \text { DE } 24, \text { DE } 25, \\
\text { DE 26, DE 27, DE } 28\end{array}$ \\
\hline & 8 & $3.77 \times 10^{8}$ & $\begin{array}{c}\text { DE 29, DE } 30, \text { DE } 31, \\
\text { DE 32, DE } 33\end{array}$ \\
\hline & 9 & $5.09 \times 10^{8}$ & DE 34, DE 35, DE 36 \\
\hline
\end{tabular}

Seven isolates were selected based on maximum scorings from the positive results of phase 1: DE-6, DE-9, DE-11, DE-12, DE-17, DE-24, and DE-29.

The Gram-staining reaction and characteristics were used to identify the selected bacterial isolates (Table 3). Morphological characteristics are further used to identify the genera of the organism (Table 4).

\section{Decolorizing POME Treated with Isolates Selected from Phase 1 Results}

\section{Optimizing POME Decolorization in Different Conditions}

To optimize the process of decolorization, a set of conditions were maintained at room temperature and at $37^{\circ} \mathrm{C}$ with shaking and static. These mixtures were maintained for a seven-day period at these temperatures in both static and shaking conditions where the absorbance values were taken in triplicate for each mixture every day for one week. These absorbance values were used to calculate the percentage of decolorization of POME using the formula given in the materials and methods section.

The result indicated that the POME treated under shaking conditions at room temperature was more effective in decolorizing the POME, as shown in Table 5. We recognised that these strains might have produced secondary metabolites or enzymes that would have been able to metabolise the phenolic compounds present in the POME. This can be noted when the color intensity of the POME decreases from thick brownish color to light brownish color. Optimum temperature conditions are
Table 2. Screening of extracellular enzymes produced by various carbohydrate-degrading isolates and their scoring.

\begin{tabular}{|c|c|c|c|c|c|c|}
\hline $\begin{array}{l}\text { Strain } \\
\text { number }\end{array}$ & Starch & $\begin{array}{l}\text { Cellu- } \\
\text { lose }\end{array}$ & Xylan & Chitin & $\begin{array}{c}\text { Positive } \\
\text { results }\end{array}$ & Scoring \\
\hline DE-1 & - & - & - & - & 0 & 0 \\
\hline DE-2 & - & - & - & - & 0 & 0 \\
\hline DE-3 & - & - & ++ & - & 1 & 2 \\
\hline DE-4 & - & - & - & - & 0 & 0 \\
\hline DE-5 & - & - & - & - & 0 & 0 \\
\hline DE-6 & +++ & - & - & ++ & 2 & 5 \\
\hline DE-7 & - & - & - & ++ & 1 & 2 \\
\hline DE-8 & $=$ & $=$ & $=$ & $=$ & 0 & 0 \\
\hline DE-9 & - & +++ & ++ & ++ & 3 & 7 \\
\hline DE-10 & - & + & $=$ & $=$ & 1 & 1 \\
\hline DE-11 & +++ & + & - & ++ & 3 & 6 \\
\hline DE-12 & - & ++ & - & +++ & 2 & 5 \\
\hline DE-13 & $=$ & + & $=$ & ++ & 2 & 3 \\
\hline DE-14 & - & - & - & +++ & 1 & 3 \\
\hline DE-15 & - & + & $=$ & ++ & 2 & 3 \\
\hline DE-16 & - & 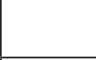 & $=$ & + & 1 & 1 \\
\hline DE-17 & +++ & + & - & ++ & 3 & 6 \\
\hline DE-18 & - & + & - & - & 1 & 1 \\
\hline DE-19 & - & - & - & ++ & 1 & 2 \\
\hline DE-20 & - & - & + & - & 1 & 1 \\
\hline $\mathrm{DE}-21$ & - & ++ & - & - & 1 & 2 \\
\hline $\mathrm{DE}-22$ & - & - & $=$ & ++ & 1 & 2 \\
\hline DE-23 & - & - & - & ++ & 1 & 2 \\
\hline DE-24 & - & ++ & +++ & - & 2 & 5 \\
\hline DE-25 & - & ++ & - & - & 1 & 2 \\
\hline DE-26 & ++ & + & - & - & 2 & 3 \\
\hline DE-27 & - & + & - & + & 2 & 2 \\
\hline DE-28 & - & + & - & - & 1 & 1 \\
\hline DE-29 & - & +++ & ++ & - & 2 & 5 \\
\hline DE-30 & - & - & - & - & 0 & 0 \\
\hline DE-31 & - & - & - & - & 0 & 0 \\
\hline DE-32 & - & ++ & ++ & - & 2 & 4 \\
\hline DE-33 & - & ++ & ++ & - & 2 & 4 \\
\hline DE-34 & - & - & - & - & 0 & 0 \\
\hline DE-35 & - & - & - & - & 0 & 0 \\
\hline DE-36 & - & - & ++ & - & 1 & 2 \\
\hline
\end{tabular}

-: No degradation, + : low growth, ++ : moderate growth, +++ : dense growth 
Table 3. Gram's reaction and characteristics of selected bacterial isolates.

\begin{tabular}{|c|c|c|c|}
\hline Strain number & Gram staining & Shape & Arrangement \\
\hline DE-6 & $(+)$ & cocci & group \\
\hline DE-9 & $(+)$ & rods & chain \\
\hline DE-11 & $(-)$ & rods & group \\
\hline DE-12 & $(+)$ & cocci & cluster \\
\hline DE-17 & $(+)$ & rods & group \\
\hline DE-24 & $(+)$ & rods & group \\
\hline DE-29 & $(-)$ & rods & group \\
\hline
\end{tabular}

+: Gram positive strain; -: Gram negative strain

where the color removal is comparatively reached and also identify the micro-organisms involved. Aeration is one of the factors for the organisms to grow in the culture as they release the secondary metabolites or enzymes actively and decolorize so effectively [13].

It was found that shaking and room temperature conditions were comparatively suited to yield the better percentage of decolorization by the selected seven isolates in a seven-day study period. Shaking conditions at room temperature gave a steady, consistent, and better percentage than at $37^{\circ} \mathrm{C}$. In room temperature shaking conditions, DE-9 and DE-11 strains showed maximum decolorization on the third day, whereas for DE-17 it was on the seventh day. The reason for this was difficult to predict unless we know the details of the strain and their characteristics. At $37^{\circ} \mathrm{C}$, the percentage of decolorization was slow and in general it was increased with the days and for the strains DE-9, DE-11, and DE-17 showing maximums on days 3,4 , and 5 , respectively. This was shown in Table 6.

The percentage of decolorization generally was reduced in static conditions compared to that of shaken conditions for even the strains that showed a good percentage of decolorization, as evidenced by Tables 7 and 8. It was also found that in static conditions at room temperature and at $37^{\circ} \mathrm{C}$ there was not much difference in decolorization. The percentage was also not steady in either the order of increase or decrease, and it was unpredictable. One of the major factors for this was the type of strain and its characteristics, and also due to the reduced supply of oxygen in static conditions for the seven-day period. Since the oxygen was depleted in the system, the bacteria were not able to produce the enzymes effectively and so were unable to clear off the color effectively. This could be a reason for the variation in the percentage of decolorization [14].

Table 4. Morphological characteristics of selected bacterial isolates.

\begin{tabular}{|c|c|c|c|c|c|c|}
\hline Strain number & Shape & Size & Margin & Color & Elevation & Form \\
\hline DE-6 & Irregular & Small & Undulate & Cream & Convex & Watery \\
\hline DE-9 & Irregular & Large & Entire & Cream & Convex & Watery \\
\hline DE-11 & Circular & Medium & Entire & Light yellowish & Flat & Mucoid \\
\hline DE-12 & Circular & Large & Entire & Orange & Convex & Mucoid \\
\hline DE-17 & Puntiform & Small & Entire & Light yellow & Convex & Mucoid \\
\hline DE-24 & Puntiform & Small & Entire & White & Convex & Rough \\
\hline DE-29 & Circular & Medium & Entire & White & Convex & Slimy \\
\hline
\end{tabular}

Table 5. Percentage of decolorization of POME (\%) treated with the selected seven isolates in shaking conditions at room temperature.

\begin{tabular}{|c|c|c|c|c|c|c|c|}
\hline \multirow{2}{*}{ Isolate Days } & \multicolumn{7}{|c|}{$\begin{array}{l}\text { Percentage of decolorization of POME }(\%) \text { in shaking } \\
\text { conditions at room temperature for seven days. }\end{array}$} \\
\hline & Day 1 & Day 2 & Day 3 & Day 4 & Day 5 & Day 6 & Day 7 \\
\hline DE-6 & $2.1 \pm 0.15$ & $2.7 \pm 0.4$ & $2.9 \pm 0.64$ & $2.7 \pm 0.92$ & $2.7 \pm 0.46$ & $2.5 \pm 0.76$ & $2.9 \pm 0.61$ \\
\hline DE-9 & $10.3 \pm 0.26$ & $21.2 \pm 1.26$ & $35.3 \pm 1.53$ & $33.3 \pm 1.53$ & $35.0 \pm 1.0$ & $35.1 \pm 1.26$ & $32.0 \pm 2.0$ \\
\hline DE-11 & $9.0 \pm 0.5$ & $12.3 \pm 1.53$ & $22.0 \pm 2.0$ & $19.2 \pm 0.76$ & $20.0 \pm 1.0$ & $17.7 \pm 2.08$ & $19.3 \pm 1.15$ \\
\hline DE-12 & $1.8 \pm 0.25$ & $3.3 \pm 0.76$ & $3.7 \pm 0.29$ & $2.2 \pm 0.76$ & $2.5 \pm 0.5$ & $2.3 \pm 0.58$ & $4.2 \pm 0.76$ \\
\hline DE-17 & $18.2 \pm 1.76$ & $20.3 \pm 1.53$ & $23.3 \pm 1.15$ & $30.0 \pm 2.0$ & $30.0 \pm 1.0$ & $27.3 \pm 1.53$ & $27.0 \pm 1.73$ \\
\hline DE-24 & $1.5 \pm 0.5$ & $2.8 \pm 0.29$ & $4.0 \pm 0.5$ & $2.0 \pm 0.5$ & $2.0 \pm 0.5$ & $2.8 \pm 0.29$ & $4.2 \pm 0.76$ \\
\hline DE-29 & $4.0 \pm 0.5$ & $6.8 \pm 0.58$ & $7.5 \pm 0.5$ & $3.8 \pm 0.29$ & $2.5 \pm 0.5$ & $3.5 \pm 0.5$ & $4.0 \pm 0.5$ \\
\hline
\end{tabular}

The percentage of decolorization (\%) values are expressed as mean \pm SD. 
Table 6. Percentage of decolorization of POME (\%) treated with selected seven isolates in shaking conditions at $37^{\circ} \mathrm{C}$.

\begin{tabular}{|c|c|c|c|c|c|c|c|}
\hline \multirow{2}{*}{ Isolate } & \multicolumn{7}{|c|}{$\begin{array}{l}\text { Percentage of decolorization of POME (\%) in shaking } \\
\text { conditions at } 37^{\circ} \mathrm{C} \text { for seven days }\end{array}$} \\
\hline & Day 1 & Day 2 & Day 3 & Day 4 & Day 5 & Day 6 & Day 7 \\
\hline DE-6 & $4.2 \pm 0.29$ & $4.8 \pm 0.76$ & $3.7 \pm 0.76$ & $4.3 \pm 0.29$ & $4.0 \pm \mathbf{0 . 5}$ & $3.8 \pm 0.29$ & $4.0 \pm \mathbf{1 . 0}$ \\
\hline DE-9 & $6.0 \pm 1.0$ & $9.0 \pm 1.0$ & $34.7 \pm 2.52$ & $27.3 \pm 1.53$ & $28.7 \pm 1.15$ & $27.0 \pm 1.0$ & $29.0 \pm 1.0$ \\
\hline DE-11 & $7.5 \pm 1.5$ & $8.0 \pm 1.0$ & $26.7 \pm 2.52$ & $19.3 \pm 0.58$ & $18.7 \pm 2.08$ & $23.7 \pm 1.53$ & $21.0 \pm 1.73$ \\
\hline DE-12 & $3.8 \pm 0.76$ & $4.3 \pm 0.58$ & $7.7 \pm 0.76$ & $8.7 \pm 0.58$ & $11.8 \pm 1.53$ & $12.5 \pm 0.5$ & $11.3 \pm 1.53$ \\
\hline DE-17 & $12.7 \pm 1.53$ & $16.3 \pm 2.08$ & $24.3 \pm 1.53$ & $20.3 \pm 0.58$ & $21.0 \pm 1.0$ & $22.0 \pm 1.0$ & $20.7 \pm 0.58$ \\
\hline DE-24 & $1.5 \pm 0.5$ & $2.2 \pm 0.29$ & $3.0 \pm \mathbf{0 . 5}$ & $3.3 \pm 0.29$ & $3.3 \pm 0.29$ & $2.7 \pm 0.76$ & $2.7 \pm 0.29$ \\
\hline DE-29 & $1.2 \pm 0.29$ & $4.0 \pm 0.5$ & $6.8 \pm 0.76$ & $7.7 \pm 0.76$ & $7.0 \pm \mathbf{0 . 5}$ & $8.0 \pm 0.5$ & $7.3 \pm 0.58$ \\
\hline
\end{tabular}

The percentage of decolorization (\%) values are expressed as mean \pm SD.

Table 7. Percentage of decolorization of POME (\%) treated with selected seven isolates in static conditions at room temperature.

\begin{tabular}{|c|c|c|c|c|c|c|c|}
\hline \multirow{2}{*}{\begin{tabular}{|} 
Isolate \\
\multirow{2}{*}{ Days }
\end{tabular}} & \multicolumn{7}{|c|}{$\begin{array}{c}\text { Percentage of decolorization of POME (\%) in static } \\
\text { conditions at room temperature for seven days. }\end{array}$} \\
\cline { 2 - 8 } & Day 1 & Day 2 & Day 3 & Day 4 & Day 5 & Day 6 & Day 7 \\
\hline DE-6 & $1.5 \pm 0.5$ & $2.0 \pm 0.0$ & $1.8 \pm 0.29$ & $1.8 \pm 0.35$ & $1.7 \pm 0.29$ & $1.4 \pm 0.4$ & $1.6 \pm 0.4$ \\
\hline DE-9 & $\mathbf{7 . 5} \pm \mathbf{0 . 8 7}$ & $\mathbf{7 . 6} \pm \mathbf{0 . 7 2}$ & $\mathbf{8 . 4} \pm \mathbf{0 . 4}$ & $\mathbf{7 . 8} \pm \mathbf{1 . 0 4}$ & $\mathbf{7 . 0} \pm \mathbf{0 . 5}$ & $\mathbf{6 . 8} \pm \mathbf{1 . 0 4}$ & $\mathbf{7 . 3} \pm \mathbf{0 . 2 6}$ \\
\hline DE-11 & $\mathbf{8 . 1} \pm \mathbf{0 . 3 6}$ & $\mathbf{9 . 7} \pm \mathbf{0 . 7 6}$ & $\mathbf{1 1 . 8} \pm \mathbf{1 . 5 3}$ & $\mathbf{1 1 . 3} \pm \mathbf{1 . 0 4}$ & $\mathbf{8 . 8} \pm \mathbf{1 . 0 4}$ & $\mathbf{9 . 7} \pm \mathbf{0 . 8 3}$ & $\mathbf{8 . 8} \pm \mathbf{0 . 5 3}$ \\
\hline DE-12 & $1.2 \pm 0.35$ & $1.4 \pm 0.4$ & $1.3 \pm 0.42$ & $1.2 \pm 0.72$ & $1.0 \pm 0.4$ & $1.0 \pm 0.2$ & $1.3 \pm 0.23$ \\
\hline DE-17 & $\mathbf{9 . 2} \pm \mathbf{0 . 8}$ & $\mathbf{1 2 . 2} \pm \mathbf{1 . 0 4}$ & $\mathbf{1 3 . 8} \pm \mathbf{0 . 7 6}$ & $\mathbf{1 6 . 5} \pm \mathbf{1 . 3 2}$ & $\mathbf{1 2 . 2} \pm \mathbf{1 . 0 4}$ & $\mathbf{1 2 . 0} \pm \mathbf{1 . 0}$ & $\mathbf{1 1 . 3} \pm \mathbf{0 . 7 6}$ \\
\hline DE-24 & $1.4 \pm 0.53$ & $2.1 \pm 0.23$ & $2.0 \pm 0.4$ & $1.2 \pm 0.25$ & $1.1 \pm 0.12$ & $1.2 \pm 0.35$ & $1.0 \pm 0.35$ \\
\hline DE-29 & $2.3 \pm 0.12$ & $3.7 \pm 0.76$ & $4.3 \pm 0.42$ & $4.5 \pm 0.31$ & $3.2 \pm 0.2$ & $3.5 \pm 0.5$ & $3.6 \pm 0.6$ \\
\hline
\end{tabular}

The percentage of decolorization (\%) values are expressed as mean $\pm \mathrm{SD}$.

The three selected potential isolates were treated with POME at two different temperatures under shaking conditions and were chosen for further investigation with $\mathrm{pH}, \mathrm{COD}$, and BOD. Among the isolates, DE-9 was shown to have the highest percentage of decolorization of POME both at room temperature and at $37^{\circ} \mathrm{C}$.

It is believed that the other environmental factors such as open light source, normal aeration, and the presence

Table 8. Percentage of decolorization of POME (\%) treated with selected seven isolates in static conditions at $37^{\circ} \mathrm{C}$.

\begin{tabular}{|c|c|c|c|c|c|c|c|}
\hline \multirow{2}{*}{ Isolate } & \multicolumn{7}{|c|}{ Percentage of decolorization of POME (\%) in static } \\
conditions at $37^{\circ} \mathrm{C}$ for seven days \\
\cline { 2 - 8 } & Day 1 & Day 2 & Day 3 & Day 4 & Day 5 & Day 6 & Day 7 \\
\hline DE-6 & $2.6 \pm 0.35$ & $2.7 \pm 0.31$ & $3.7 \pm 0.23$ & $4.1 \pm 0.42$ & $2.8 \pm 0.61$ & $2.8 \pm 0.42$ & $3.0 \pm \mathbf{0 . 2}$ \\
\hline DE-9 & $\mathbf{3 . 5} \pm \mathbf{0 . 3}$ & $\mathbf{4 . 5} \pm \mathbf{0 . 4 2}$ & $\mathbf{5 . 7} \pm \mathbf{0 . 4 2}$ & $\mathbf{6 . 3} \pm \mathbf{0 . 3 1}$ & $\mathbf{5 . 8} \pm \mathbf{0 . 8 7}$ & $\mathbf{5 . 2} \pm \mathbf{0 . 2}$ & $\mathbf{5 . 5} \pm \mathbf{0 . 3 1}$ \\
\hline DE-11 & $\mathbf{5 . 2} \pm \mathbf{0 . 3 5}$ & $\mathbf{6 . 2} \pm \mathbf{0 . 2}$ & $\mathbf{1 0 . 9} \pm \mathbf{1 . 1}$ & $\mathbf{1 1 . 0} \pm \mathbf{1 . 5}$ & $\mathbf{1 4 . 1} \pm \mathbf{0 . 9}$ & $\mathbf{9 . 1} \pm \mathbf{0 . 9 6}$ & $\mathbf{9 . 3} \pm \mathbf{0 . 4 2}$ \\
\hline DE-12 & $1.6 \pm 0.15$ & $3.0 \pm \mathbf{0 . 5}$ & $3.5 \pm 0.0$ & $3.7 \pm 0.29$ & $2.5 \pm 0.5$ & $2.3 \pm 0.61$ & $2.9 \pm 0.81$ \\
\hline DE-17 & $\mathbf{6 . 6} \pm \mathbf{0 . 6}$ & $\mathbf{5 . 5} \pm \mathbf{0 . 4 2}$ & $\mathbf{7 . 9} \pm \mathbf{0 . 7}$ & $\mathbf{9 . 0} \pm \mathbf{0 . 2}$ & $\mathbf{1 0 . 5} \pm \mathbf{0 . 5}$ & $\mathbf{1 1 . 6} \pm \mathbf{1 . 2 1}$ & $\mathbf{1 1 . 2} \pm \mathbf{1 . 0 4}$ \\
\hline DE-24 & $1.8 \pm 0.53$ & $2.5 \pm \mathbf{0 . 3}$ & $3.7 \pm 0.76$ & $3.4 \pm 0.35$ & $3.3 \pm 0.4$ & $3.2 \pm 0.2$ & $3.6 \pm 0.15$ \\
\hline DE-29 & $1.5 \pm 0.64$ & $2.6 \pm 0.6$ & $3.7 \pm 0.5$ & $3.8 \pm 0.29$ & $3.2 \pm 0.76$ & $3.3 \pm 0.29$ & $3.6 \pm 0.4$ \\
\hline
\end{tabular}

The percentage of decolorization (\%) values are expressed as mean $\pm \mathrm{SD}$. 


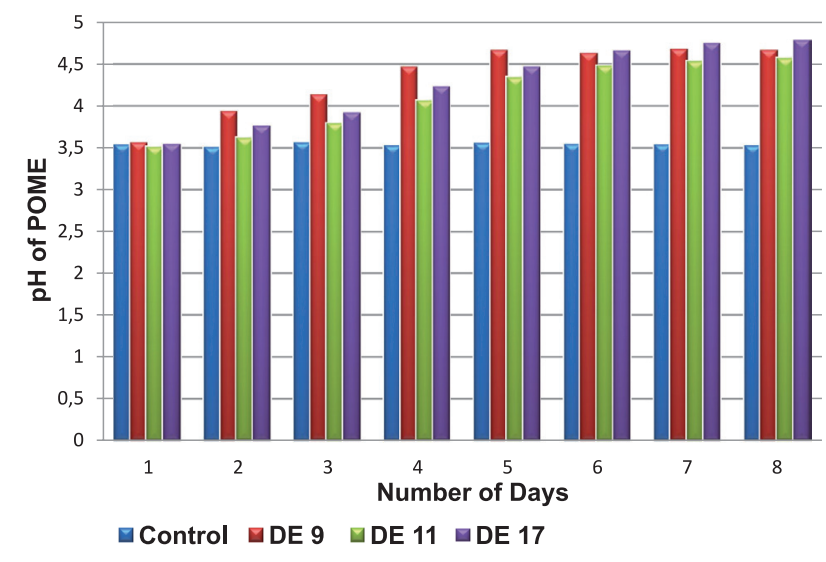

Fig. 1. $\mathrm{pH}$ values of POME treated with three potential isolates DE 9,11 , and 17 - in a seven-day period.

of humidity also contribute to decolorization and were shown here as the reason why at room temperature POME was effectively cleared off by the organisms [15].

The initial values of $\mathrm{pH}, \mathrm{BOD}$, and COD of POME were taken before the POME was treated with the selected potential isolates. The $\mathrm{pH}$ values of the POME treated by the best three isolates under shaking conditions at room temperature for the seven days of the period were measured using a standard $\mathrm{pH}$ meter. The original $\mathrm{pH}$ value of the POME was found to be 3.5. Fig 1.shown for the $\mathrm{pH}$ values of POME after treatment with the three isolates indicated that the $\mathrm{pH}$ was slowly increased. It was evidenced that the acidity of POME was significantly reduced after the treatment and until the end of day 7. This was probably due to the nature of the strains involved, which reduced the overall acidity of the POME. A perusal of the literature showed that soil-isolated bacteria such as Bacillus cereus, Bacillus polymyxa, Bacillus megaterium, and various other Bacillus sp were capable of breaking down the carbohydrate contained in POME [16].

BOD and COD values were taken for the three potential isolates on days 3 and 7 of bacterially treated POME to confirm the decolorization done by the isolates. The significantly decreased values of BOD and COD indicated that the POME had been treated by these isolates, and the toxicity of POME was reduced by reducing the total dissolved solids. When BOD levels were high, dissolved oxygen levels decreased because the oxygen that was available in the POME was being consumed by the bacteria. The decreased level of COD here was a useful indicator to say that the isolates were significantly involved in the reduction of total dissolved solids. The COD results from Table 9 indicated the same as explained by Clair et al. (2003) [17].

The use of aerobic bacteria in the POME treatment minimize the environmental pollution caused by the palm oil mill industry. Also, the production cost is less and easier to handle. And although it is time consuming, they comply with environmental regulations. We have done the preliminary studies on the strains from the soil to characterize them.

\section{Conclusions}

The disadvantages of physical and chemical methods of degradation and remediation are producing dangerous by-products that require intensive energy, and the processes involved are quite expensive. But the use of biological methods such as bioremediation or microbial bioconversion are less costly, more effective, environmentally friendly, and very safe overall. These micro-organisms are used to break down the organic materials contained in the effluent so as to clear the color and toxic wastes present in them. Hence, the three aerobic soil isolates - DE-9, DE-11, and DE-17 - have the potential to decolorize the POME optimized at shaken conditions and room temperature. If the characterization study on isolates could have been extended it would be useful to generate data on the area of bioremediation.

\section{Acknowledgements}

MAHSA University for financial support.

\section{References}

1. ALI HUDDIN IBRAHIM., IRVAN DAHLAN., MOHD NORDIN ADLAN, AREZOO FEREIDONIAN DASTI. Comparative Study on Characterization of Malaysian Palm Oil Mill Effluent. Research Journal of Chemical Sciences, Volume 2 (12), 1, 2012.

2. ALIYU SALIHU, MD. ZAHANGIR ALAM. Palm oil mill effluent: a waste or a raw material? Journal of Applied Sciences Research, Volume 8 (1), 466, 2012.

Table 9. BOD and COD values of POME (mg/l) treated with three potential isolates on days 3 and 7.

\begin{tabular}{|c|c|c|c|c|c|c|c|}
\hline $\begin{array}{l}\text { Parameters } \\
\text { Isolates }\end{array}$ & \multirow{2}{*}{$\begin{array}{l}\text { Before } \\
\text { treatment }\end{array}$} & \multicolumn{2}{|c|}{ DE-9 } & \multicolumn{2}{|c|}{ DE-11 } & \multicolumn{2}{|c|}{ DE-17 } \\
\hline \multirow{2}{*}{$\begin{array}{l}\text { Chemical oxygen demand } \\
\text { (COD) }(\mathrm{mg} / \mathrm{l})\end{array}$} & & Day 3 & Day 7 & Day 3 & Day 7 & Day 3 & Day 7 \\
\hline & 72,500 & 69,800 & 67,000 & 68,000 & 66,500 & 70,000 & 65,000 \\
\hline $\begin{array}{l}\text { Biological oxygen demand } \\
\text { (BOD) }(\mathrm{mg} / \mathrm{l})\end{array}$ & 31,000 & 29,000 & 28,500 & 28,000 & 27,000 & 30,000 & 28,500 \\
\hline
\end{tabular}

The values of BOD and COD are expressed as $\mathrm{mg} / \mathrm{l}$. 
3. CHIN HONG NEOH., ADIBAH YAHYA., ROBIAH ADNAN., ZAITON ABDUL MAJID., ZAHARAH IBRAHIM Optimization of decolorization of palm oil mill effluent (POME) by growing cultures of Aspergillus fumigatus using response surface methodology. Environmental Science and Pollution Research International, 20, 2912, 2012.

4. CHANIDA RAKAMTHONG, POONSUK PRASERTAN Decolorization and Phenol Removal of Anaerobic Palm Oil Mill Effluent by Phanerochaete chrysosporium ATCC 24725. TIChE International Conference, 2011.

5. IGWE J.C., ONYEGBADO C.C. A Review of Palm Oil Mill Effluent (POME) Water Treatment. Global Journal of Environmental Research, 1 (2), 54, 2007.

6. HOLT J.G., KRIEG N.R., SNEATH P.H.A., STALEY J.T., WILLIAMS S.T. Bergey's Manual of Determinative Bacteriology. $9^{\text {th }}$ Ed.; Williams and Wilkins. 71, 1994.

7. KUNAL MADHAV., SATISH VERMA., RITU TANTA Isolation of amylase producing Bacillus species, from soil sample of different regions in Dehradun and to check the effect of $\mathrm{pH}$ and Temperature on their amylase activity. Journal of Pharmaceutical and Biomedical Sciences, 12, 1, 2011.

8. MUHAMMAD IRFAN., ASMA SAFDAR., QURATULAIN SYED., MUHAMMAD NADEEM. Isolation and screening of cellulolytic bacteria from soil optimization of cellulase production and activity. Turkish Journal of Biochemistry, 37 (3), 287, 2012.

9. SAOWAPAR KHIANNGAM., SOMBOON TANASUPAWAT., ANCHARIDA AKARACHARANYA., KWANG KYU KIM, KEUN CHUL LEE., JUNGSOOK LEE Paenibacillus xylanisolvens sp. nov., a xylandegrading bacterium from soil. International Journal of Systemic and Evolutionary Microbiology, 61, 160, 2011.
10. PRIYA C.S., JAGANNATHAN N., KALAICHELVAN P.T. Production of chitinase by Streptomyces hygroscopicus $v m c h 2$ by optimisation of cultural conditions. International Journal of Pharma and Bio Sciences, 2, B-210, 2011.

11. AWAIS AMIN., SHINAWAR WASEEM ALI., RUBINA ARSHAD., SHAHID NADEEM., SIKANDER ALI Characterization of chitinolytic bacterial strains isolated from local habitat. Mycopath, 9 (2), 51, 2011.

12. VASSANASAK LIMKHUANSUWAN, PAWINEE CHAIPRASERT. Decolorization of molasses melanoidins and palm oil mill effluent phenolic compounds by fermentative lactic acid bacteria. Journal of Environmental Sciences, 22 (8), 1209, 2010.

13. RONALD M.TEATHER, PETER J. WOOD Use of Congo Red-Polysaccharide Interactions in Enumeration and Characterization of Cellulolytic Bacteria from the Bovine Rument. Applied and Environmental Microbiology, 43, 777, 1982.

14. REVELLE P., REVELLE C. Environmental protection, Human ecology, $3^{\text {rd }}$ ed; ISBN 0867200723, Jones and Bartlett publishers, 1998.

15. SUPAWADEE SINNARAPRASAT, PRAYOON FONGSATITKUL Optimal Condition of Fenton's Reagent to Enhance the Alcohol Production from Palm Oil Mill Effluent (POME). Environmental Asia, 4 (2), 9, 2011.

16. JEREMIAH DAVID BALA., JAPARENG LALUNG., NORLI ISMAIL Biodegradation of palm oil mill effluent (POME) by bacteria. International Journal of Scientific and Research Publications, 4 (3), 1, 2014.

17. CLAIR N., SAWYER., PERRY L. McCARTY., GENE F. PARKIN Chemistry for Environmental Engineering and Science, $5^{\text {th }}$ ed.; McGraw-Hill. ISBN 0-07-248066-1, New York, 2003. 